\title{
Evaluation of the anatomical relationship between mandibular third molars and the mandibular canal using Cone Beam Computed Tomography
}

\author{
Avaliação da relação anatômica entre os terceiros molares mandibulares e o canal mandibular por \\ meio de Tomografia Computadorizada Cone Beam
}

Evaluación de la relación anatómica entre los terceros molares mandibulares y el canal mandibular mediante tomografía computarizada Cone Beam

Received: 05/01/2021 | Reviewed: 05/20/2021 | Accept: 05/24/2021 | Published: 06/09/2021

\author{
Magno Vinícius Silva Batista \\ ORCID: https://orcid.org/0000-0001-9918-8629 \\ Amazonas State University, Brazil \\ E-mail: magnovsbatista@gmail.com \\ Joel Motta Junior \\ ORCID: https://orcid.org/0000-0003-0272-5163 \\ Amazonas State University, Brazil \\ E-mail: jmotta@uea.edu.br
}

\begin{abstract}
Objective: This study aims to establish the anatomical relationship between the mandibular canal and the third molars, based on analysis by Cone Beam Computed Tomography. Methodology: Computed Tomography analysis of 67 third molars was performed using Blue Sky Plan 4 virtual planning software. The anatomical dispositions of the third molars and mandibular canal were evaluated, as well as the factors that favor the contact between these structures. Result: There was a prevalence of $76.1 \%$ for biradicular third molars, $52.2 \%$ for class 1 and $71.6 \%$ class A. Vertical and mesioangulated teeth had a higher prevalence, with $38.8 \%$ and $35.8 \%$ respectively. Sicher and Tandler's classification presented $41.8 \%$ of the canals as type I, while in the buccal-lingual positioning, $89.5 \%$ of the canals were located through the buccal. $44.8 \%$ of the teeth had contact with the canal and the factors with statistical significance were: female gender $(p=0.019)$, number of roots $(p=0.019)$, class $3(p=0.004)$ and $C(p=0.012)$ teeth and lingual positioning of the mandibular canal $(\mathrm{p}=0.016)$. About the anatomical delimitations, the mean diameter of the canal was $3.14 \mathrm{~mm}$ and the distances related to the dental roots, lingual, buccal and inferior cortical bony were $2.77,3.53,4.56$ and 8.32 milimeters, respectively. Conclusion: Therefore, the assessment of third molars by computed tomography is essential during preoperative planning, as it identifies anatomical relationships that favor contact between the tooth and the mandibular canal and helps to reduce the incidence of sensorineural disorders.
\end{abstract}

Keywords: Inferior alveolar nerve; Third molar; Cone beam computed tomography.

\section{Resumo}

Objetivo: Esse estudo visa estabelecer a relação anatômica entre o canal mandibular e os terceiros molares, a partir de análise por Tomografias Computadorizadas Cone Beam. Metodologia: Foi realizada análise de Tomografias Computadorizadas de 67 terceiros molares em software de planejamento virtual Blue Sky Plan 4. Foram avaliadas as disposições anatômicas dos terceiros molares e do canal mandibular, bem como os fatores que favorecem o contato entre essas estruturas. Resultado: Notou-se prevalência de 76,1\% para terceiros molares birradiculares, 52,2\% para classe 1 e 71,6\% classe A. Houve maior prevalência de dentes verticais e mesioangulados, com 38,8\% e 35,8\% respectivamente. A classificação de Sicher e Tandler apresentou 41,8\% dos canais como tipo I, enquanto no posicionamento vestíbulo-lingual, $89,5 \%$ dos canais apresentaram-se localizados pela vestibular. 44,8\% dos dentes apresentaram contato com o canal e os fatores que apontaram significância estatística foram: gênero feminino $(\mathrm{p}=0,019)$, número de raízes $(\mathrm{p}=0,019)$, dentes classe $3(\mathrm{p}=0,004)$ e $\mathrm{C}(\mathrm{p}=0,012)$ e posicionamento lingual do canal mandibular $(\mathrm{p}=0,016)$. Em relação às delimitações anatômicas, o diâmetro médio do canal foi de $3,14 \mathrm{~mm}$ e as distâncias relativas às raízes dentárias e corticais ósseas lingual, vestibular e inferior foram de 2,77, 3,53, 4,56 e 8,32 milímetros, respectivamente. Conclusão: Portanto, a avaliação dos terceiros molares por tomografias computadorizadas é essencial durante o planejamento pré-operatório, pois identifica relações anatômicas que favorecem o contato entre dente e o canal mandibular e auxilia na redução da incidência de distúrbios neurossensoriais.

Palavras-chave: Nervo alveolar inferior; Terceiro molar; Tomografia computadorizada de feixe cônico. 


\begin{abstract}
Resumen
Objetivo: Este estudio tiene como objetivo establecer la relación anatómica entre el canal mandibular y los terceros molares, a partir del análisis por Tomografía Computarizada Cone Beam. Metodología: El análisis de Tomografía Computarizada de 67 terceros molares se realizó mediante el software de planificación virtual Blue Sky Plan 4. Se evaluó la disposición anatómica de los terceros molares y del canal mandibular, así como los factores que favorecen el contacto entre ellos. Resultado: hubo prevalencia en 76,1\% para terceros molares birradiculares, 52,2\% para clase 1 y $71,6 \%$ clase A. Hubo mayor prevalencia de dientes verticales y mesioangulados, con 38,8\% y 35,8\% respectivamente. Clasificación de Sicher y Tandler presentó $41,8 \%$ de los canales como tipo I, mientras que en posicionamiento vestibulo-lingual, $89,5 \%$ de los canales se ubicaron por vestibular. $44.8 \%$ de los dientes tuvieron contacto con canal y los factores que mostraron significancia estadística fueron: género femenino ( $\mathrm{p}=0.019)$, número de raíces $(\mathrm{p}=0.019)$, dientes clase $3(\mathrm{p}=0.004)$ y $\mathrm{C}(\mathrm{p}=0.012)$ y posicionamiento lingual del canal mandibular $(\mathrm{p}=0,016)$. En cuanto las delimitaciones anatómicas, el diámetro medio del conducto fue de 3,14 mm y las distancias relacionadas con las raíces dentales y huesos corticales, lingual, vestibular y inferior fueron de 2,77, 3,53, 4,56 y 8,32 mm, respectivamente. Conclusión: Por consiguiente, la valoración de terceros molares mediante tomografía computarizada es fundamental durante la planificación preoperatoria, porque identifica relaciones anatómicas que favorecen el contacto entre diente y el canal mandibular y ayuda a reducir la incidencia de trastornos neurosensoriales.
\end{abstract}

Palabras clave: Nervio alveolar inferior; Tercero molar; Tomografía computarizada de haz cónico.

\title{
1. Introduction
}

The extraction of mandibular third molars is the most commonly performed oral and maxillofacial surgery procedure in clinical practice. Approximately $40 \%$ of these teeth are completely or partially covered by bone and may be associated with pathological manifestations, such as infectious, cystic or tumor alterations, therefore, surgical indication is frequent (Deshpand et al., 2013; Gu et al., 2018). However, due to the close anatomical relationship between the apical region of the roots of the third mandibular molars and the mandibular canal, neurosensory disorders of the lower alveolar nerve, such as dysesthesias and paresthesias, are serious complications that can develop in the postoperative period (Gu L et al., 2018), with a prevalence of approximately 0.4 to $6 \%$ (Cheung et al., 2010; Valmaseda-Castellón et al., 2001).

Preoperative radiographic evaluation is essential to determine the proximity between anatomical structures and the possibility of injury to the nerve during the surgical approach. The radiographic exams most commonly requested for preoperative evaluation are panoramic radiographs and cone beam computed tomography (CBCT) (Deshpand P et al., 2013).

Panoramic radiography is the most requested image exam for preoperative evaluation in extractions of third molars, due to its low cost and greater accessibility. However, it provides only a two-dimensional image, with wide overlapping of structures and difficulties in the precise determination of the buccal-lingual position of the third molars (Deshpand $\mathrm{P}$ et al., 2013; Monaco et al., 2004; Sedaghatfar et al., 2005).

Cone Beam Computed Tomography (CBCT) has been widely used due to its high spatial resolution, three-dimensional capacity with the possibility of reconstruction in axial, coronal and sagittal sections. In addition, it provides the precise anatomical location of the mandibular canal in the buccal-lingual and anteroposterior directions (Deshpand et al., 2013; Kim and Lee, 2014). Therefore, CBCT has been recommended in cases where there is close contact between the mandibular canal and the third molar, previously identified on panoramic radiography (Ghaeminia $\mathrm{H}$ et al., 2009).

In this context, the aim of this work is to establish the three-dimensional anatomical relationship between the mandibular canal and the third mandibular molars, based on the analysis of Cone Beam Computed Tomography, in order to guide the elaboration of an adequate surgical planning, identifying anatomical relationships that favor contact between the roots and the lower alveolar nerve and may increase the risk of nerve damage during surgery. 


\section{Methodology}

\section{Ethical aspects}

The research protocol complies with resolutions 466/2012, of the National Health Council, Ministry of Health, Brazil. This study was approved by the Research Ethics Committee of the University of the State of Amazonas (CAAE 51507615.4.0000.5016). All patients in this study signed a Free and Informed Consent Form, granting access to the data contained in their computed tomography exams.

\section{Materials}

This study consisted of a cross-sectional observational investigation, carried out at the Dental Polyclinic of the University of the State of Amazonas (Manaus-AM, Brazil), having as reference the departments of maxillofacial Surgery and traumatology and dental imaging.

The eligibility criteria were tomographic examinations of patients seen at the maxillofacial surgery and traumatology outpatient clinic of the Dental Polyclinic of the University of the State of Amazonas in 2015. The study included patients with mandibular third molars, without distinction of gender, ethnicity or age. Those who did not present third mandibular molars or with incomplete rhizogenesis, individuals with mandibular fractures, residual roots or pathologies, such as cysts and mandibular tumors, were excluded.

Forty-five Cone-Beam computed tomography images in DICOM format were analyzed using Blue Sky Plan 4 virtual planning software. To evaluate the exams, sagittal, axial, coronal sections and 3D reconstruction were used, as well as tools for measurement of distances to the cortical bone and precise delimitation of the extension of the mandibular canal.

\section{Methods}

The sample was evaluated regarding the positioning of the third mandibular molars, the anatomical relationship between the mandibular canal and the roots of the third molar, the presence of contact between the mandibular canal and dental roots and the relative dimensions of the mandibular canal in relation to the bone cortices.

\section{Evaluation of mandibular third molars and mandibular canal:}

The third molars were evaluated for the number of roots, classified according to the classifications of Pell and Gregory (1933), Winter (1926), Sicher and Tandler (1977) and for the buccal-lingual positioning of the mandibular canal in relation to the roots of the third molar.

\section{a) Number of roots}

The third mandibular molars were evaluated for the number of roots in: Uniradicular, biradicular and triradicular.

b) Pell e Gregory classifications (1933)

\section{Relationship with the anterior border of the mandibular ramus}

Class 1: Mesiodistal diameter of the crown completely anterior to the anterior margin of the mandibular ramus.

Class 2: Approximately $50 \%$ of the mesio-distal diameter of the crown covered by the bone of the mandibular ramus.

Class 3: The third molar is located completely within the mandibular ramus.

\section{Relationship with the occlusal plane}

Class A: Occlusal surface of the third molar is at or near the level of the occlusal plane of the second molar.

Class B: Occlusal surface of the third molar is between the occlusal plane and the cervical line of the second molar.

Class C: Occlusal surface of the third molar is below the cervical line of the second molar. 
The third molar is classified according to the relationship between the long axis of the third molar and the long axis of the adjacent second molar.

Mesioangulated: Third molar is inclined mesially to the second molar.

Distoangulated: Third molar is inclined distally or posteriorly to the second molar.

Vertical: Long axis of the third molar is parallel to the second molar.

Horizontal: Long axis of the third molar is perpendicular to the second molar.

Linguoangulated: Third molar is displaced lingually in relation to the second molar.

\section{d) Buccal-lingual positioning of the mandibular canal in relation to the roots of the third molar}

The mandibular canal was evaluated for buccal-lingual positioning with roots of the third molar.

Vestibular: The mandibular canal is located by the buccal aspect of the roots of the third molar.

Lingual: The mandibular canal is located by the lingual aspect of the roots of the third molar.

\section{e) Sicher and Tandler classification (1977)}

The mandibular canal was classified according to the anteroposterior position in relation to the roots of the third molar.

Type I: The mandibular canal is in close contact with the bottom of the third molar alveolus and distances from the roots of the other molars.

Type II: The mandibular canal is distant from all mandibular molars and premolars.

Type III: The mandibular canal is in close contact with the apexes of the molars and second premolar.

\section{Assessment of the prevalence of contact between the third molar and the mandibular canal:}

The correlation of variables was observed gender, number of roots, Pell and Gregory classifications, Winter angulation, Sicher and Tandler classification and buccal-lingual positioning of the canal, with the prevalence of contact between the mandibular canal and the third molars.

\section{Analysis of the anatomical dimensions of the mandibular canal:}

Canal diameter, relative distance from the mandibular canal to the roots of the third molars and to the buccal, lingual and basilar cortical bones of the mandible were measured.

\section{Statistical analysis:}

The collected data were organized in a Microsoft Office Excel spreadsheet version 2010 and later, subjected to a ChiSquare test by the SPSS Statistics version 19.0 program.

\section{Results}

After analyzing cone beam computed tomography (CBCT) examinations of 45 patients, 67 mandibular third molars were identified, $33(49.25 \%)$ of which belong to female gender and $34(50.75 \%)$ to the male gender. The average age of the patients was 34.18 years.

In assessing the position of the third mandibular molar, in relation to the number of dental roots, $51(76.12 \%)$ birradicular third molars were detected, while the uni or tri-radicular teeth showed a frequency of $6(8.96 \%)$ and $10(14.92 \%)$ respectively.

About the Pell and Gregory classification regarding the relation of the third molar with the anterior border of the mandibular ramus (figure 1A), 35 (52.23\%) teeth were classified as class 1. In relation to the occlusal plane (figure 1B), there was a greater predilection for third molars classified as class A, with 48 (71.64\%) teeth identified. 
In the Winter classification analysis (figure 1C), there was a predominance of teeth in vertical angulation, with 26 (38.80\%), followed by mesioangulated with 24 (35.82\%) teeth. The lowest frequency observed for third linguoangulated molars, with only three $(4.48 \%)$ teeth.

Figure 1. Evaluation of the positioning of the third molar. A - Classification of Pell and Gregory about the relationship with the mandibular ramus. B - Pell and Gregory classification about the relationship with the occlusal plane. C - Winter angulation.

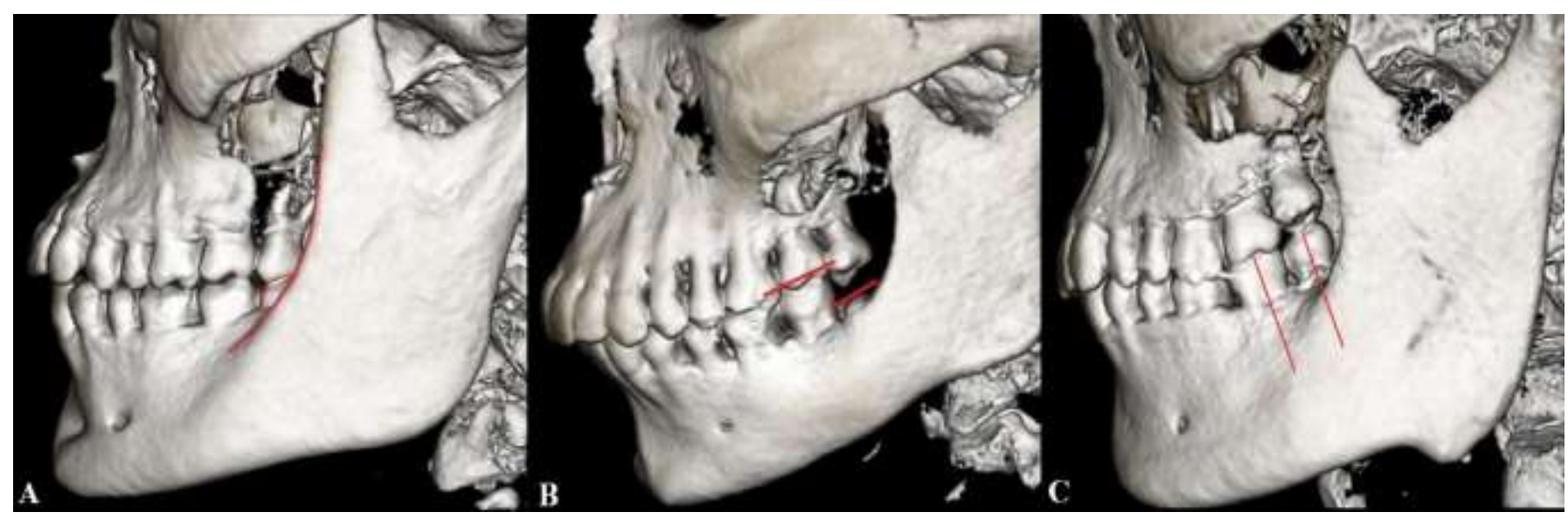

Source: Autors. (Blue Sky Plan 4 software images).

In the evaluation of the positioning of the mandibular canal in relation to the roots of the third molars, in the anteroposterior aspect, according to the classification of Sicher and Tandler (figure 2A), there was a slight predilection for type I canals, with $28(41.8 \%)$ identified. In the classification about the buccal-lingual position (figure 2B), the canals were located by the buccal aspect of the roots in $60(89.5 \%)$ third molars.

Figure 2. Evaluation of the relationship between the third molars and the mandibular canal. A - Sicher and Tandler's classification of the anteroposterior position of the mandibular canal. B - Bucco-lingual positioning of the mandibular canal.

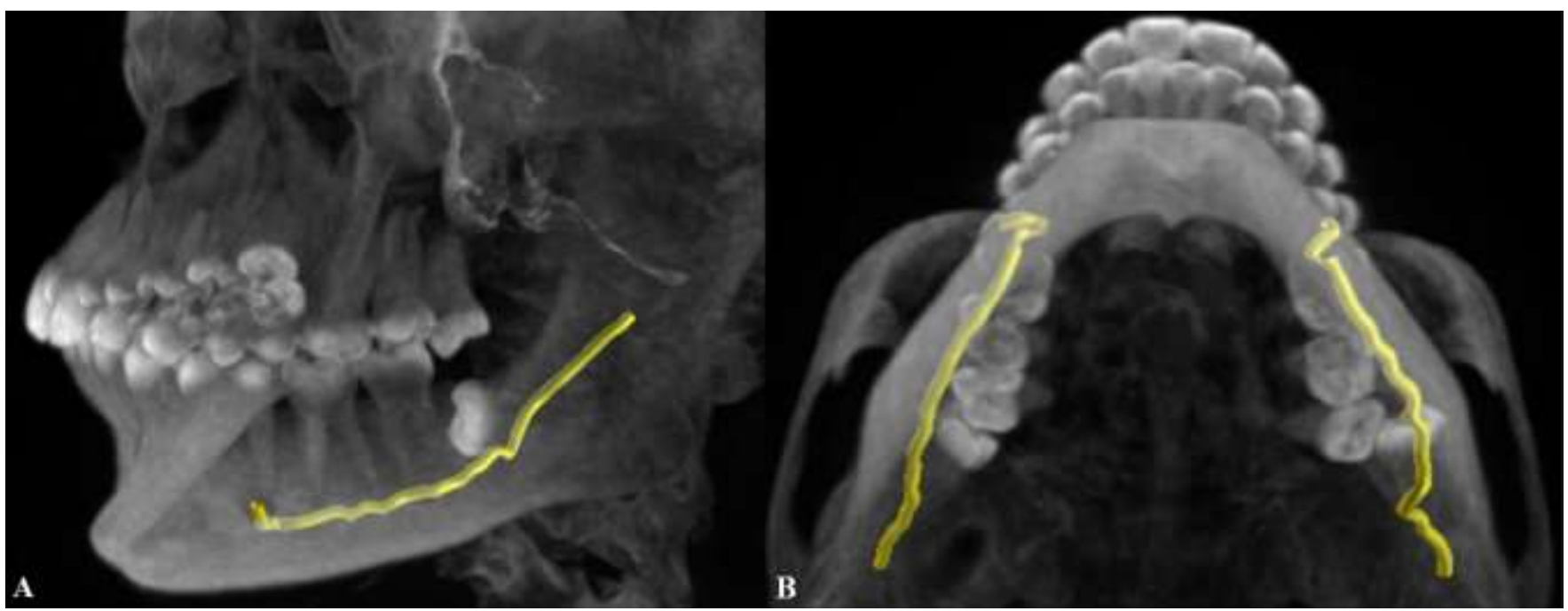

Source: Autors. (Blue Sky Plan 4 software images).

In assessing the contact between the mandibular canal and the roots of the third molars (figure 3), 30 (44.78\%) teeth presented contact with the mandibular canal. Table 1 describes the correlation of the variables addressed in the study with the 
prevalence of contact between the teeth and the mandibular canal. A Chi-square test was performed using the statistical analysis software SPSS Statistics 19.0 and the variables that influenced the increase in the prevalence of contact between the third molar and the mandibular canal with statistically relevant results $(\mathrm{p}<0.05)$ were: Number of roots $(p=0.019)$, in which three-root teeth are associated with contact with the mandibular canal in $80 \%$ of cases. Pell and Gregory classification, where a higher prevalence of contact was observed in teeth classified as class $3(\mathrm{p}=0.004)$ and class $\mathrm{C}(0.012)$, both with $100 \%$ of cases. The lingual positioning of the mandibular canal showed a prevalence of contact with the roots of the third molar in $100 \%$ of the cases $(\mathrm{p}=0.016)$. In assessing prevalence by gender, the female gender represented $64.9 \%$ of cases of contact between third molars and the mandibular canal $(\mathrm{p}=0.019)$. The other variables did not show statistically significant results.

Figure 3. Assessment of the presence of contact between the third molars and the mandibular canal.

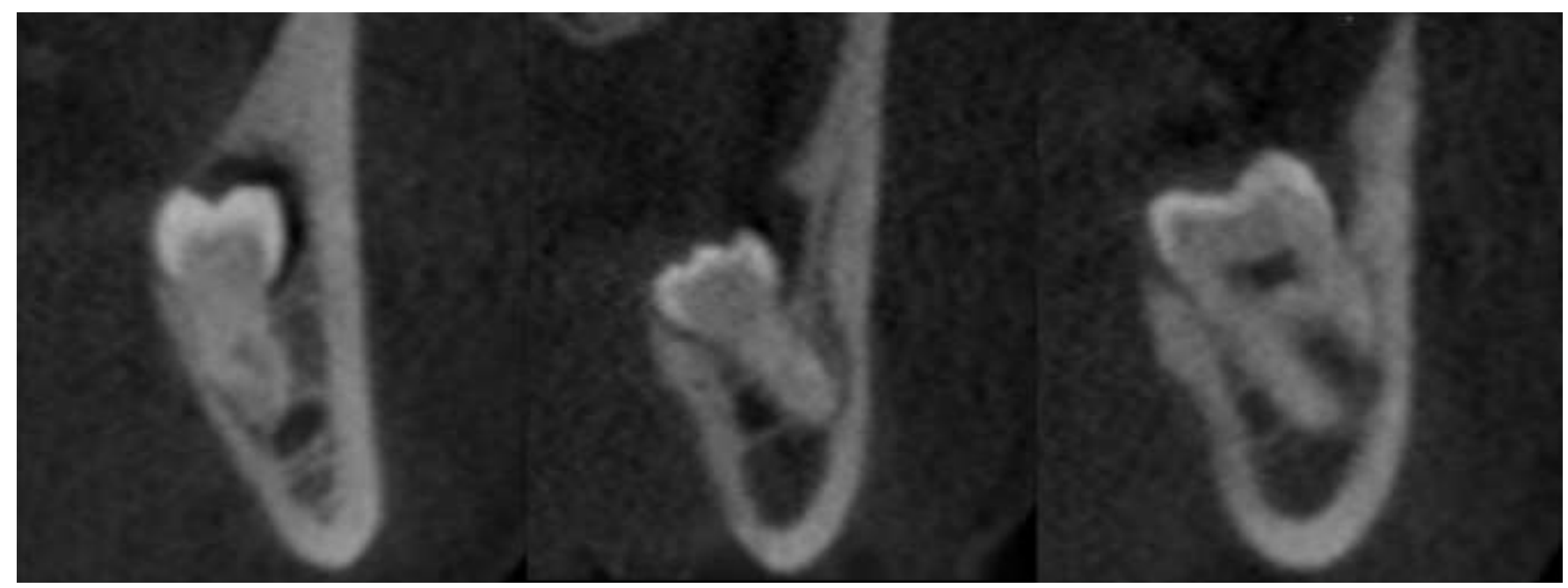

Source: Autors. (Blue Sky Plan 4 software images).

Table 1. Prevalence of contact between the mandibular canal and mandibular third molars according to the variables and classifications mentioned.

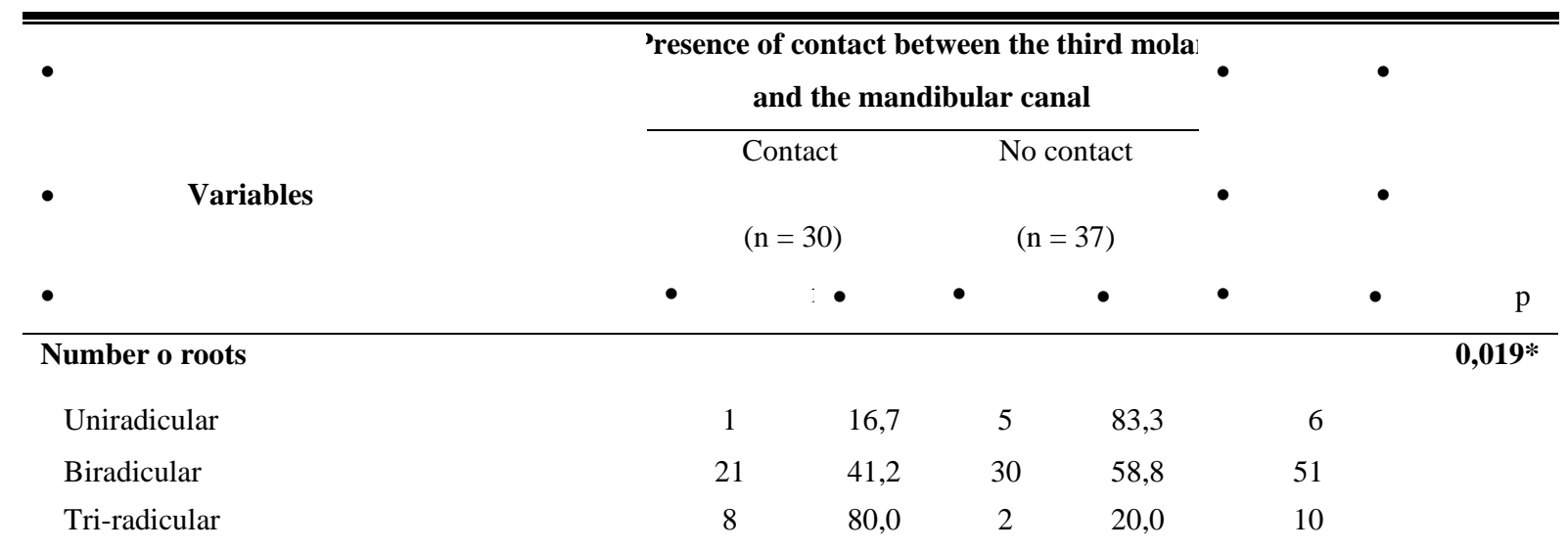

Pell and Gregory classification: Relationship with the mandibular ramus

Class 1

Class 2

Class 3
25,7

58,6

100,0

\section{6}

12

0

74,3
41,4
0,0


Pell and Gregory classification: Relationship with the oclusal plane

Class A

Class B

Class C

\section{Winter classification}

Mesioangulated
Distoangulated
Vertical
Horizontal
Linguoangulated

Sicher e Tandler classification

Type I

Type II

Type III

Bucco-lingual positioning

Buccal

Lingual

Gender

Female
Male

$\begin{array}{rrrrr}16 & 33,3 & 32 & 66,7 & 48 \\ 5 & 50,0 & 5 & 50,0 & 10 \\ 9 & 100,0 & 0 & 0,0 & 9\end{array}$

0,053

$\begin{array}{rrrrr}14 & 58,3 & 10 & 41,7 & 24 \\ 3 & 42,9 & 4 & 57,1 & 7 \\ 6 & 23,1 & 20 & 76,9 & 26 \\ 5 & 71,4 & 2 & 28,6 & 7 \\ 2 & 66,7 & 1 & 33,3 & 3\end{array}$

$13 \quad 46,4 \quad 15 \quad 53,6 \quad 28$

$\begin{array}{lllll}0 & 0,0 & 19 & 100,0 & 19\end{array}$

$\begin{array}{lllll}17 & 85,0 & 3 & 15,0 & 20\end{array}$

0,016*

$\begin{array}{lllll}7 & 100,0 & 0 & 0,0 & 7\end{array}$

$0,019 *$ 28 19 60 7

$\begin{array}{lllll}20 & 64,9 & 13 & 35,1 & 33\end{array}$

$\begin{array}{lllll}10 & 35,1 & 24 & 64,9 & 34\end{array}$

* Statistically significant results $(\mathrm{p}<0.05)$. Source: Autors.

The measurements used to establish the diameter of the mandibular canal and the anatomical distances between the bone cortex of the mandibular canal and the lingual, buccal and basilar cortical of the mandible are represented in Figure 4. While Table 2 represents the measured values of the canal distances: to the roots of the third molar, with an average of 2.77 $\mathrm{mm}$, to the inferior bony cortex of $8.32 \mathrm{~mm}$, to the lingual cortex of $3.53 \mathrm{~mm}$, to the buccal cortex of $4.56 \mathrm{~mm}$ and the diameter of the mandibular canal obtained an average of $3.14 \mathrm{~mm}$. 
Figure 4. Measurement of the diameter of the mandibular canal and anatomical distances to the buccal, lingual and basilar bony cortical bone.

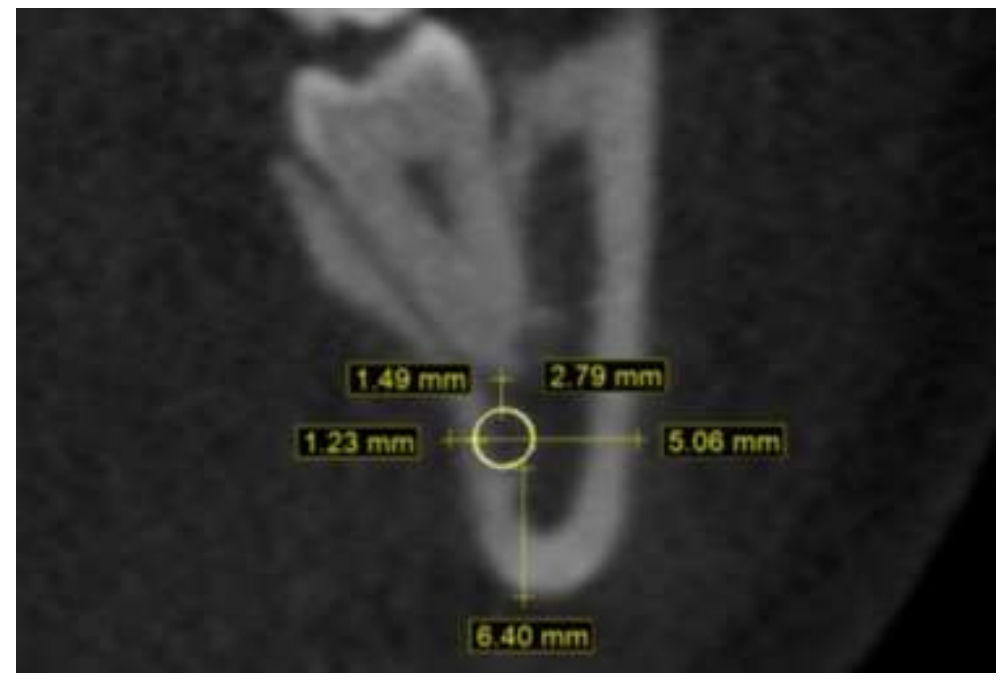

Source: Autors. (Blue Sky Plan 4 software images).

Table 2. Anatomical dimensions and distances from the mandibular canal to adjacent teeth and bone structures.

\begin{tabular}{ccc} 
Anatomical dimensions & Mean (mm) & Standard Deviation \\
Distance between the mandibular canal and roots of the third molars & 2,77 & 3,71 \\
Distance between the mandibular canal and the inferior cortical bone & 8,32 & 2,02 \\
Distance between the mandibular canal and cortical lingual bone & 3,53 & 1,50 \\
Distance between the mandibular canal and the cortical buccal bone & 4,56 & 3,14 \\
Diameter of the mandibular canal & 0,50 \\
\hline
\end{tabular}

Source: Autors.

\section{Discussion}

The extraction of third molars is the most common procedure for maxillofacial surgery. Numerous studies point to the risk of injuries to the lower alveolar nerve in the postoperative period, due to the proximity between the dental roots and the mandibular canal (Cheung et al., 2013; Valmaseda-Castellon et al., 2001; Monaco et al., 2004), therefore, an adequate preoperative evaluation is necessary to identify the anatomical relationships between the mandibular third molar and the lower alveolar nerve and the potential risk of injuries.

Panoramic radiography is an image exam most commonly requested for preoperative radiographic evaluation of the third molars, however, it provides only two-dimensional images and is unable to identify the adequate buccal-lingual relationship between the mandibular canal and the third molar (Monaco et al., 2004; Sedatghafar et al., 2005; Maegawa et al., 2003). A series of studies highlights the importance of further diagnostic investigation using Cone Beam Computed Tomography, especially when observing contiguity between anatomical structures previously on panoramic radiography (Monaco et al., 2004; Ohman et al., 2006; Mahasantipiya et al., 2005). The CBCT exams make it possible to reconstruct the images in a three-dimensional form and are more efficient in visualizing the number, shape of the roots, location, diameter and respective distances from the anatomical structures to the mandibular canal (Suomalainen et al., 2010; Susarla et al., 2007; Tantanapornkul et al., 2007). 
In the present study, the average age of the individuals was 34, 2 years, in agreement with the data found in the study by Mahasanpitiya et al. (2005), who found an average of 35 years. Male individuals represented $51 \%$ of the sample, similar to the $53.1 \%$ found in the population studied by Gupta et al. (2011). About the assessment of the third molar, a prevalence of $76.1 \%$ was observed for biradicular teeth, a result similar to the $74.1 \%$ obtained by Kim and Lee (2014). The classification proposed by Pell and Gregory in relation to the mandibular ramus, revealed a higher prevalence of teeth in class 1 position, agreeing with the results of Primo et al. (2017), however, in disagreement with Monaco et al. (2004) and Gupta et al. (2011), who reported a predilection for teeth classified as class 2. With regard to the relationship with the occlusal plane, $71.6 \%$ of the teeth were classified as class A, a result equivalent to those of Gupta et al. (2011) and diverging with the studies by Peker et al. (2014) and Primo et al. (2017). When evaluating Winter's angulation, there was a higher prevalence of teeth classified as verticals and mesioangulated, a result that is similar to that described by several authors (Sedaghatfar et al., 2005; Gupta et al., 2011; Almendroz-Marqués et al., 2006; Miloro \& DaBell. 2005).

In assessing the positioning of the mandibular canal in its anteroposterior aspect, according to the classification proposed by Sicher and Tandler, $41.8 \%$ of the canals were classified as type I, a value different from that found by Figún and Garino (2003), who reported a higher prevalence of canals classified as type II. Regarding the buccal-lingual relationship with the third mandibular molar, the literature presents a wide variety of results. In the present study, the canal presented a frequency of $89.5 \%$ located through the buccal root dental, agreeing with authors such as Kim and Lee (2014) and Maegawa et al. (2003), however, in disagreement with other studies that reported a higher prevalence of lingual or apical third molars (Ghaeminia et al., 2009; Ohman et al., 2006; Tantanapornkul et al., 2007; Peker et al., 2014).

In assessing the contact between the roots of the third molar and the mandibular canal, $44.8 \%$ of the teeth had contact with the mandibular canal. In contrast, the studies by Gu et al. (2018) and Peker et al. (2014) reported a prevalence of 7.3\% and $71.5 \%$, respectively. As described by Monaco et al (2004) and Sedaghatfar et al (2005), this close relationship between the third molar and the mandibular canal is the main factor associated with the development of sensorineural disorders in the postoperative period. In the correlation of the variables studied with the prevalence of contact between dental roots and the mandibular canal, there was a statistically relevant result, with $\mathrm{p}>0.05$, for teeth classified as class 3 and class $\mathrm{C}$ by Pell and Gregory, with a prevalence of $100 \%$ in both in cases, results similar to those described by Monaco et al. (2004). Regarding the buccal-lingual positioning, teeth positioned by the lingual also showed statistically significant results, in agreement with studies by $\mathrm{Gu}$ et al. (2018) and Mahasantipiya et al. (2005), in addition, in these cases there is also a higher incidence of exposure of the lower alveolar nerve in the trans-surgical and neurosensory disorders in the postoperative period, as reported by Maegawa et al. (2003) and Nakayama et al. (2009). In this study, the female gender is also associated with statistically significant results for contact with the nerve, a result that is contrary to the studies by Kim and Lee (2014), who did not demonstrate a statistically significant relationship between gender and the presence of contact between dental roots and the mandibular canal. About the Winter and Sicher and Tandler classifications, there was no statistically significant result.

Data related to the dimensions of the mandibular canal are still insufficient in the literature. Among the few studies found, Maravilha (2016) published in its evaluation of 45 third molars by means of Cone Beam Computed Tomography exams, parallel results about the anatomical dimensions, especially regarding the diameter of the mandibular canal, with 3.23 $\mathrm{mm}$, compared to $3.14 \mathrm{~mm}$ in the present study.

In this context, this study confirmed the clinical utility of Cone Beam Computed Tomography for preoperative evaluation of third molars, however, although the results indicate a statistically significant correlation between certain anatomical dispositions and the contact between the canal and the dental roots, additional studies incorporating new analyzes and more numerous samples will be indispensable to justify the findings of the present study. 


\section{Final Considerations}

In conclusion, it is possible to infer that cone beam computed tomography scans are fundamental for preoperative evaluation, as they identify the anatomical relationships that favor the contact between the mandibular canal and third molars and can be useful resources to minimize the occurrence of sensorineural disorders that develop in the postoperative period, making surgical treatment more predictable and comfortable.

\section{References}

Almendroz-Marqués, N., Berini-Aytés, L., \& Gay-Escoda, C. (2006). Influence of lower third molar positions on the incidence of preoperative complications. Oral Surg Oral Med Oral Pathol Oral Radiol Endod, 102:725-32.

Cheung, L. K., Leung, Y. Y., Chow, L. K., Wong, M. C. M., Chan, E. K. K., \& Fok, Y. H. (2010). Incidence of neurosensory deficits and recovery after lower third molar surgery: a prospective clinical study of 4338 cases. Int J Oral Maxillofac Surg, 39:320-326.

Deshpande, P., Guledgud, M. V., \& Patil, K. (2013). Proximity of Impacted Mandibular Third Molars to the Inferior Alveolar Canal and Its Radiographic Predictors: A Panoramic Radiographic Study. J. Maxillofac. Oral Surg, 12(2):145-151.

Figún, M. E., \& Garino, R. R. (2003). Anatomia odontológica funcional e aplicada. Artmed.

Ghaeminia, H., Meijer, G. J., Soehardi, A., Borstlap, W. A., Mulder, J., \& Berge, S. J. (2009). Position of the impacted third molar in relation to the mandibular canal. Diagnostic accuracy of cone beam computed tomography compared with panoramic radiography. Int J Oral Maxillofac Surg, 38:964-971.

Gu, L., Zhu, C., Chen, K., Liu, X., \& Tang, Z. (2018). Anatomic study of the position of the mandibular canal and corresponding mandibular third molar on conebeam computed tomography images. Surg Radiol Anat, 40: 609-614.

Gupta, S., Bhowate, R. R., Nigam, N., \& Saxena, S. (2011). Evaluation of impacted mandibular third molars by panoramic radiography. ISRN Dent, 8p.

Kim, H. G., \& Lee, J. H. (2014). Analysis and evaluation of relative positions of mandibular third molar and mandibular canal impacts. J Korean Assoc Oral Maxillofacial Surg, 40:278-284

Maegawa, H., et al. (2003). Preoperative assessment of the relationship between the mandibular third molar and the mandibular canal by axial computed tomography with coronal and sagital reconstruction. Oral Surg Oral Med Oral Pathol. Oral Radiol Endod., 96: 639-46.

Mahasantipiya, P. M., Savage, N. W., Monsour, P. A., \& Wilson, R. J. (2005). Narrowing of the inferior dental canal in relation to the lower third molars. Dentomaxillofac Radiol, 34:154-63

Maravilha, T. A. R. Avaliação tridimensional da relação do canal mandibular com a posição radicular do terceiro molar mandibular. [Dissertação de mestrado]. Instituto de ciências da Saúde da Universidade Católica Portuguesa; (2016). 103 p. Mestrado em medicina dentária.

Miloro, M., \& DaBell, J. (2005). Radiographic proximity of the mandibular third molar to the inferior alveolar canal. Oral Surg Oral Med Oral Pathol Oral Radiol Endod, 100:545-9.

Monaco, G., Montevecchi, M., Alessandri Bonetti, G., Gatto, M. R. A., \& Checchi, L. (2004). Reliability of panoramic radiography in evaluating the topographic relationship between the mandibular canal and impacted third molars. J Am Dent Assoc. 135:312-318.

Nakayama, K., Nonoyama, M., Takaki, Y., Kagawa, T., Yuasa, K., Izumi, K., Ozeki, S., \& Ikebe, T. (2009). Assessment of the relationship between impacted mandibular third molars and inferior alveolar nerve with dental 3-dimensional computed tomography. J Oral Maxillofac Surg 67:2587-91.

Ohman, A., Kivijarvi, k.. Blomback, U., \& Flygare, L. (2006). Pre-operative radiographic evaluation of lower third molars with computed tomography. Dentomaxillofac Radiol, 35: 30-35.

Peker, I., Sarikir, C., Alkurt, M. T., \& Zor, Z. F. Panoramic radiographic and cone beam computed tomography findings in preoperative examination of impacted third molars. BMC Oral Health. 14:71.

Primo, F. T., Primo, B. T., Scheffer, M. A. R., Hernández, P. A. G., \& Rivaldo, E. G. (2017). Evaluation of 1211 third molars positions according to the classification of Winter, Pell \& Gregory. Int. J. Odontostomat, 11(1):61-65.

Sedaghatfar, M., August, M. A., \& Dodson, T. B (2005). Panoramic radiographic findings as predictors of inferior alveolar nerve exposure following third molar extraction. J Oral Maxillofac Surg, 63:3-7

Suomalainen, A., Ventä, I., Mattila, M., Turtola, L., Vehmas, T., \& Peltola, J. S. (2010). Reliability of CBCT and other radiographic methods in preoperative evaluation of lower third molars. Oral Surg Oral Med Oral Pathol Oral Radiol Endod, 109:276-84.

Susarla, S. M., \& Dodson, T. B. (2007). Preoperative computed tomography imaging in the management of impacted mandibular third molars. J Oral Maxillofac Surg; 65:83-8.

Tantanapornkul, W., Okouchi, K., Fujiwara, Y., Yamashiro, M., Maruoka, Y., Ohbayashi, N., \& Kurabayashi, T. (2007). A comparative study of cone-beam computed tomography and conventional panoramic radiography in assessing the topographic relationship between the mandibular canal and impacted third molars. Oral Surg Oral Med Oral Pathol Oral Radiol Endod, 103: 253-259.

Valmaseda-Castellon, E., Berini-Aytes, L., \& Gay-Escoda, C. (2001). Inferior alveolar nerve damage after lower third molar surgical extraction: a prospective study of 1,117 surgical extractions. Oral Surg Oral Med Oral Pathol Oral Radiol Endod, 92:377-383. 